\title{
Mannan binding lectin deficiency and concomitant immunodefects
}

\author{
J Aittoniemi, M Baer, E Soppi, T Vesikari, A Miettinen
}

\begin{abstract}
Objective-To determine the prevalence of a mannan binding lectin (MBL) deficiency in children with increased susceptibility to infections and to investigate whether other coexisting immunodeficiencies affecting opsonisation are needed to render MBL deficiency clinically significant.

Patients and methods-343 serum samples were collected from 266 children with repeated infections, a single episode of severe infection, or prolonged symptoms relating to infection. The concentrations of MBL, immunoglobulin G (IgG), M $(\operatorname{IgM}), A(\operatorname{IgA})$, and IgG subclasses $\left(\operatorname{IgG}_{1-4}\right)$ were analysed.

Results-MBL deficiency was found in nine children $(3.2 \%)$, seven of whom had repeated infections or a single episode of severe infection. In two, initial symptoms and signs suggestive of infection eventually led to the diagnosis of an autoimmune disease-Still's disease in one and pauciarticular juvenile rheumatoid arthritis in the other. Among the children with MBL deficiency and infections, concomitant IgG subclass deficiency was detected in five and a transient low level of one or two IgG subclasses in two. Prevalence of an IgG subclass deficiency in children with MBL deficiency was higher than in those without (56\% and $22 \%$, respectively).

Conclusions-MBL deficiency alone is not an independent risk factor for infection but may be manifested in association with another humoral immunodeficiency affecting opsonisation. Among children with MBL deficiency, those with juvenile rheumatoid arthritis were overrepresented. This calls for further study. (Arch Dis Child 1998;78:245-248)
\end{abstract}

Keywords: mannan binding lectin; IgG subclasses; immunodeficiency; opsonisation

Mannan binding lectin (MBL) is a serum acute phase protein secreted by the liver with a function resembling that of the complement component C1q. MBL binds to mannose and $\mathrm{N}$-acetylglucosamine structures on the surface of yeasts and bacteria, opsonising these for polymorphonuclear phagocytes independently of antibodies and activating the complement system through the classical pathway.

Approximately $5.3 \%$ of the Finnish population have MBL deficiency, defined as an undetectable level of MBL in the serum. ${ }^{2}$ A large proportion of these individuals are asympto- matic. ${ }^{12}$ On the other hand, patients with MBL deficiency and increased susceptibility to severe repeated infections of the skin, respiratory tract, and gastrointestinal tract have been described. $^{3}{ }^{4}$ Therefore MBL deficiency alone may not cause people to be susceptible to infection but may act as a cofactor in some individuals. Conversely, other coexisting factors may be needed to render the MBL deficiency clinically significant.

The aim of our study was to determine the prevalence of MBL deficiency in children with increased susceptibility to infection, and to investigate whether other coexisting immunodeficiencies affecting opsonisation are needed to render the MBL deficiency clinically significant.

\section{Methods}

The study plan was accepted by the ethical committee of the Medical School, University of Tampere, Tampere, Finland.

\section{PATIENTS}

We studied 343 sera from 266 children, collected between 1988 and 1992. The children were initially seen at the paediatric infectious disease clinic, Tampere University Hospital, because of repeated infections, a single episode of severe infection, or prolonged symptoms relating to infection. Serum specimens were collected for the analysis of immunoglobulin $\mathrm{G}(\operatorname{IgG}), \mathrm{M}(\operatorname{Ig} \mathrm{M}), \mathrm{A}(\operatorname{Ig} \mathrm{A})$, and $\mathrm{IgG}$ subclasses $\left(\mathrm{IgG}_{1-4}\right)$. Successive serum samples were taken from certain children who had low concentrations of IgG subclasses in the first sample and were under clinical consideration for treatment with intravenous gamma globulin. The specimens were stored frozen at $-70^{\circ} \mathrm{C}$ until assay for $\mathrm{MBL}$.

The mean age of the children at the time of the first blood samples was 4.9 years (range 0.1 to 15.9 years). There were 104 girls, mean age 5.3 years (range 0.5 to 15.9 years), and 162 boys, mean age 4.7 years (range 0.1 to 15.8 years).

\section{LABORATORY ASSAYS}

Serum MBL concentrations were determined by an enzyme immunoassay, as previously described. ${ }^{2}$ The detection limit of the assay was $0.02 \mathrm{mg} / 1$; values below the limit were regarded as indicating MBL deficiency.

Serum concentrations of total IgG, IgM, and IgA were determined by nephelometric assay according to the manufacturer's instructions (Behringwerke AG, Marburg, Germany). Serum concentrations of IgG subclasses were measured by radial immunodiffusion assay. ${ }^{5}$ 
Table 1 Characteristics of seven children with a mannan binding lectin (MBL) deficiency and increased susceptibility to bacterial infections

\begin{tabular}{|c|c|c|c|c|c|}
\hline Sex & $\begin{array}{l}\text { Age at onset of } \\
\text { symptoms }\end{array}$ & Clinical characteristics at presentation & $\begin{array}{l}\text { Age at } M B L \\
\text { determination }\end{array}$ & $\begin{array}{l}\text { Coexisting immunological } \\
\text { defects or abnormalities }\end{array}$ & $\begin{array}{l}\text { Other factors associated with } M B L \text { deficiency or } \\
\text { child's symptoms. Present state of health }\end{array}$ \\
\hline M & Birth & $\begin{array}{l}\text { Recurrent otitis media and lower } \\
\text { respiratory tract infections }\end{array}$ & 1 Year 8 months & $\mathrm{IgG}_{3}$ deficiency & $\begin{array}{l}\text { Wet lung syndrome at birth, minor stenosis of } \\
\text { the trachea. Susceptibility to infections } \\
\text { decreased }\end{array}$ \\
\hline $\mathrm{F}$ & 9 Months & $\begin{array}{l}\text { Purulent skin infections, recurrent } \\
\text { otitis media, lower respiratory } \\
\text { tract infections, failure to thrive }\end{array}$ & 12 Years & $\begin{array}{l}\mathrm{IgG}_{3} \text { deficiency, transient } \\
\text { low } \mathrm{IgG}_{2} \text { and high IgE }\end{array}$ & $\begin{array}{l}\text { Severe atopic eczema and bronchial asthma. } \\
\text { Susceptibility to infections decreased }\end{array}$ \\
\hline M & 1 Month & $\begin{array}{l}\text { Recurrent otitis media, maxillary } \\
\text { sinusitis, and lower respiratory } \\
\text { tract infections }\end{array}$ & 4 Years 1 month & $\begin{array}{l}\mathrm{IgG}_{4} \text { deficiency and } \\
\text { transient low } \mathrm{IgG}_{2}\end{array}$ & Susceptibility to infections decreased \\
\hline $\mathrm{F}$ & 5 Months & $\begin{array}{l}\text { Severe purulent tracheobronchitis } \\
\text { with acute respiratory distress } \\
\text { syndrome at age } 5 \text { months. } \\
\text { Thereafter repeated lower } \\
\text { respiratory tract infections }\end{array}$ & 5 Years 11 months & $\mathrm{IgG}_{4}$ deficiency & $\begin{array}{l}\text { Subglottic stenosis caused by tracheobronchitis } \\
\text { and prolonged intubation; operated on at } 3 \\
\text { years. Susceptibility to infections decreased }\end{array}$ \\
\hline M & 1 Year, 1 month & $\begin{array}{l}\text { Severe } S \text { aureus lymphadenitis of } \\
\text { the neck }\end{array}$ & 1 Year 2 months & $\operatorname{IgG}_{4}$ deficiency & $\begin{array}{l}\text { After lymphadenitis no increased susceptibility } \\
\text { to infections }\end{array}$ \\
\hline $\mathrm{F}$ & 3 Months & $\begin{array}{l}\text { Recurrent otitis media and lower } \\
\text { respiratory tract infections }\end{array}$ & 3 Years 1 month & Transient low $\operatorname{IgG}_{2}$ & $\begin{array}{l}\text { Gastro-oesophageal reflux and bronchial } \\
\text { hyperreactivity. Susceptibility to infections } \\
\text { decreased }\end{array}$ \\
\hline M & 1 Year & $\begin{array}{l}\text { Recurrent otitis media and } \\
\text { maxillary sinusitis }\end{array}$ & 3 Years 6 months & $\begin{array}{l}\text { Transient low } \mathrm{IgG}_{2} \text { and } \\
\mathrm{IgG}_{4}\end{array}$ & $\begin{array}{l}\text { Atopic eczema and bronchial asthma. Repeated } \\
\text { maxillary sinusitis }\end{array}$ \\
\hline
\end{tabular}

Briefly, oxoid monoclonal antibodies (Unipath, Basingstoke, Hampshire, UK) M09018 (anti-IgG $)_{1}, \quad$ M1015 (anti-IgG $)_{2}, \quad M 08010$ (anti-IgG 3 ), M16013 and M11013 (anti-IgG ) were incorporated as antisera in $0.1 \mathrm{M}$ barbitone acetate ( $\mathrm{pH} \quad 8.6$ ) buffered $1 \%$ agarose (FMC BioProducts, Rockland, Maine, USA) with 7\% PEG 3000 (Fluka Chemie, Buchs, Switzerland). Antisera were used at dilutions of $12.1,20.0,2.1$, and $12.0(6.0+$ 6.0) $\mu 1 / \mathrm{ml}$ of agarose gel, respectively. Serum samples from the patients were assayed at dilutions of $1: 2$ and $1: 4$ (and also $1: 8$ for $\operatorname{IgG}_{1}$ ). Standard sera SPS-015 were used undiluted and at dilutions of $1: 2,1: 4,1: 8$, and 1:16. Sample volumes of $5 \mu \mathrm{l}$ were placed in $3 \mathrm{~mm}$ wells and allowed to diffuse at $4^{\circ} \mathrm{C}$ for one week. After diffusion, the gels were fixed in $1 \%$ glutaraldehyde and stained with amino black. The diameters of the ring shaped precipitates were measured by a radial immunodiffusion plate reader. IgG subclass concentrations of the patients' samples were calculated from the standard curve. Concentrations $\leqslant 50 \%$ of the lower limit of the age related $95 \%$ reference interval were regarded as indicating a deficiency. Those concentrations below the age related $95 \%$ reference interval but above the cutoff for deficiency were regarded as low.

IgE concentrations were determined by radioimmunoassay for selected patients as required on the basis of clinical symptoms.

STATISTICAL ANALYSIS

The prevalence of an IgG subclass deficiency was compared between different groups using Fisher's exact test.

\section{Results}

The mean and median serum concentrations of MBL in the initial serum samples taken from each of the 266 children studied were 10.19 and $8.64 \mathrm{mg} / \mathrm{l}$, respectively (range, $<0.02$ to $53.75 \mathrm{mg} / \mathrm{l})$.

MBL deficiency was found in nine children $(3.2 \%)$, seven of whom suffered from repeated infections or had had a single episode of severe infection. The clinical characteristics of these children are shown in table 1 . In the remaining two children, initial symptoms and signs suggestive of infection eventually led to the diagnosis of an autoimmune disease. One child had Still's disease complicated by pericarditis with pericardial effusion and heart failure, pleuritis, the formation of ascites, hepatitis, and a period of disseminated intravascular coagulation. In the other child, juvenile rheumatoid arthritis was diagnosed at the age of two years. She had raised titres of antinuclear antibodies and was positive for the major histocompatibility complex class I antigen HLA-B27.

Of the children with MBL deficiency and infections, concomitant IgG subclass deficiency was detected in five, accompanied by a transient low concentration of another IgG subclass in two. In two children, only a transient low concentration of one or two IgG subclasses was detected. In one child with $\mathrm{IgG}_{3}$ deficiency and a transient low concentration of $\mathrm{IgG}_{2}$, an extremely high serum concentration of IgE was also observed (up to $42650 \mathrm{IU} / \mathrm{l}$ ).

The prevalence of an IgG subclass deficiency in children with MBL deficiency was higher than in those without $(56 \%$ and $22 \%$, respectively; $\mathrm{p}=0.016$ ). 


\section{Discussion}

Our aim in this study was to investigate the prevalence and significance of MBL deficiency in children with increased susceptibility to infection. A concentration of MBL below the detection limit of the assay was defined as a significant defect in MBL mediated response.

Although Garred et al have suggested that only MBL genotypes homozygous for the mutant alleles have increased susceptibility to infection, ${ }^{6}$ Summerfield et al found that people with a heterozygous genotype were also susceptible to infection. ${ }^{7}$ In line with other findings, this implies that reduced concentrations of MBL may predispose the host to infection as well as total deficiency of MBL. ${ }^{34} 8$

The mean and median serum concentrations of MBL in our study population were similar to those observed earlier in age related healthy individuals. ${ }^{2}$ In fact, the prevalence of MBL deficiency was slightly lower than in the general Finnish population, suggesting - in contrast to the above findings - that MBL deficiency is not an independent risk factor for infection.

Of nine children with MBL deficiency, seven suffered from repeated infections or had a single episode of severe infection. Of these, five had a concomitant IgG subclass deficiency, and a transient low level of one or two IgG subclasses was detected in two. Also the prevalence of an IgG subclass deficiency was higher in children with MBL deficiency than in those without. Taken together, these findings suggest that a deficiency of MBL may become clinically manifest only when it occurs in association with another form of humoral immunodeficiency that affects opsonisation. Such a combined immunodeficiency was proposed by Turner et al in 1991, although studies supporting the hypothesis have not been published. ${ }^{9}$

In some children, the onset of symptoms coincided with the disappearance of maternal antibodies, as is typically seen with IgG subclass deficiency. Furthermore, in most of the children the symptoms decreased with advancing age, corresponding with the probable normalisation of low levels of the IgG subclasses. These findings suggest that concomitant IgG subclass deficiency is necessary before MBL deficiency results in infection. Conversely, since it is uncertain whether $\operatorname{IgG}_{3}$ or $\operatorname{IgG}_{4}$ deficiency alone can increase susceptibility to infection, MBL deficiency may have a role in potentiating the clinical effects of such deficiency.

In one child with an MBL deficiency and increased susceptibility to infections, an extremely high serum IgE concentration was detected, suggestive of the hyper-IgE syndrome. The crucial immunological defect exposing patients with this syndrome to infection is obscure. It is known, however, that the formation of a specific antibody response against microbial antigens during an infection or after vaccination is impaired. ${ }^{10}$ Therefore in patients with the hyper-IgE syndrome the role of MBL as a cofactor in opsonisation may be particularly important, as deficiency of MBL could further increase the susceptibility of these patients to severe infection.
Bronchial asthma or atopic eczema was observed in two children with MBL deficiency. An atopic constitution is more prevalent in children with a common opsonising defect than in healthy controls. ${ }^{11}$ The common opsonising defect, in turn, is strongly associated with MBL deficiency. ${ }^{3}$ For unknown reasons, an atopic constitution is also associated with increased susceptibility to infection. ${ }^{12}{ }^{13}$ The role of MBL deficiency in modifying the clinical manifestations of atopic constitution requires further study.

Three children had other underlying conditions that might have affected their susceptibility to infection. One child had gastro-oesophageal reflux. Its treatment with cisapride had no apparent effect on the child's susceptibility to infection. The second child had tracheal stenosis, which was shown at bronchoscopy to cause less than a $20 \%$ obstruction of the trachea and was considered clinically insignificant. In the third child, the severe primary infection led to permanent airway damage which was apparently a factor contributing to the child's continuing susceptibility to lower respiratory tract infections for several years. In none of these three children, however, could the increased susceptibility to infection be accounted for solely by the underlying conditions.

In two of the nine children with MBL deficiency, an immunological disease was diagnosed. One child had Still's disease, while the other initially appeared to have pauciarticular juvenile rheumatoid arthritis. After a spontaneous remission period of a few months, she developed symptoms and signs resembling dermatomyositis. MBL deficiency is a minor risk factor for systemic lupus erythematosus. ${ }^{14}$ The significance of the MBL deficiency as an aetiological factor for other immunological diseases is unknown. ${ }^{15}$ In this study, patients with juvenile rheumatoid arthritis were overrepresented among those with MBL deficiency. This finding calls for further study on the possible role of MBL deficiency as a risk factor for juvenile rheumatoid arthritis.

This study was supported by a grant from the Medical Research Fund of Tampere University Hospital, Tampere, Finland.

1 Turner MW. Mannose-binding lectin: the pluripotent molecule of the innate immune system. Immunol Today 1996;17:532-40.

2 Aittoniemi J, Miettinen A, Laippala P, et al. Age-dependent variation in the serum concentration of mannan-binding protein. Acta Paediatr 1996;85:906-9.

3 Super M, Thiel S, Lu J, et al. Association of low levels of mannan-binding protein with a common defect of opsonisation. Lancet 1989;ii:1236-9.

4 Summerfield JA, Ryder S, Sumiya M, et al. Mannose binding protein gene mutations associated with unusual and ing protein gene mutations associated with unusual

5 Milford Ward A, White PAE, French MAH, et al. A calibraion material for IgG subclass assay. $\mathcal{F}$ Clin Lab Immunol 1984;14:209-10.

6 Garred P, Madsen HO, Hofmann B, et al. Increased frequency of homozygosity of abnormal mannan-bindingprotein alleles in patients with suspected immunodeficiency. Lancet 1995;346:941-3.

7 Summerfield JA, Sumiya M, Levin M, et al. Association of mutations in mannose binding protein gene with childhood infection in consecutive hospital series. BMF 1997;314: 1229-32.

8 Sumiya M, Super M, Tabona P, et al. Molecular basis of opsonic defect in immunodeficient children. Lancet 1991; 337:1569-70.

9 Turner MW, Super M, Singh S, et al. Molecular basis of a common opsonic defect. Clin Exp Allergy 1991;21(suppl $1): 182-8$. 
10 Buckley RH. Disorders of the IgE system. In: Bralow L, Mills L, Chattin D, et al, eds. Immunologic disorders in infant 989:316-28.

11 Richardson VF, Larcher VF, Price JF. A common congenital immunodeficiency predisposing to infection and atopy in infancy. Arch Dis Child 1983;58:799802 .

12 Tainio V-M, Savilahti E, Salmenperä L, et al. Risk factors for infantile recurrent otitis media: atopy but not type of feeding. Pediatr Res 1988;23:509-12.
13 Ruuska T. Occurrence of acute diarrhea in atopic and nonatopic infants: the role of prolonged breast-feeding. $\mathcal{F}$ Pediatr Gastroenterol Nutr 1992;14:27-33.

14 Davies EJ, Snowden N, Hillarby MC, et al. Mannosebinding protein gene polymorphism in systemic lupus erythematosus. Arthritis Rheum 1995;38:110-14.

15 Malhotra R, Wormald MR, Rudd PM, et al. Glycosylation changes of IgG associated with rheumatoid arthritis can activate complement via the mannose-binding protein. Nat Med 1995;1:237-43.

\section{Good genes, bad mutations, and marrow cells}

Do you find it as confusing as I do that when geneticists refer to the gene for a disease they mean the gene which stops you having the disease not the mutation that causes it? Thus the gene for neurofibromatosis type 1 (NF1) encodes neurofibromin, a protein that acts on oncogenic Ras proteins to produce a tumour suppressor effect but the mutant gene which causes NF1 results in the production of inactive neurofibromin. In theory though, it takes the inactivation of both tumour suppressor gene alleles in somatic cells to produce malignant change and, NF1 being dominantly inherited, people with NF1 have a normal and an abnormal gene. They are predisposed to develop tumours of neural tissue and young children with the condition have a 200 to 500 fold increase in risk of myeloid malignancy. So why this predisposition to malignancy in heterozygotes who ought to be protected by their normal gene?

Workers in California (Lucy Side and colleagues, New England fournal of Medicine 1997;336:1713-20) examined bone marrow cells from 18 children with NF1 and malignant myeloid disorders. They found abnormal neurofibromin peptides in nine and truncating mutations of the NF1 gene in eight. In five specimens the cells contained no normal NF1 gene. Examination of affected parents showed that the abnormal genes in leukaemic cells were inherited and not somatic mutations. It is suggested, therefore, that malignancy occurs when the normal NF1 allele in somatic cells is inactive. Other factors favouring malignant change are male sex, maternal inheritance, and loss of chromosome 7. Work on mice suggests that it may be possible to develop anti-Ras protein drugs which could prove effective against some malignancies.

ARCHIVIST 